\title{
Sayıştayların Denetlenmesi: Ülke Uygulamaları ve Türkiye
}

\author{
İsmail CİĞERCİ*, Ali BALKI**
}

ÖZ

Sayıştaylar, her ülkede kamu kurumlarının hesaplarını ve mallarını denetleyen yüksek denetim kuruluşlarıdır. Kamu kurumlarının denetimi gibi sayıştayların da hesapları ile yapmış olduğu iş ve işlemlerin denetlenmesi gerekmektedir. Ülke sayıştaylarının denetlenmesi konusunda; meslektaş değerlendirmesi, bağımsız denetim kuruluşları tarafından yapılan inceleme ve diğer bir ülke sayıştayınca yapılan inceleme olmak üzere üç farklı yöntem izlenmektedir. Özellikle son on yıllık dönemde Uluslararası Yüksek Denetim Kurumları Teşkilatının (INTOSAI) da desteklediği ve büyük önem verdiği meslektaş değerlendirmesi ön plana çıkmaktadır. Bu çalışmada, iyi uygulama örnekleri üzerinden sayıştayların nasıl denetimden geçtiği ve bu anlamda Türkiye örneği incelenmiş olup; Türk Sayıştayının meslektaş değerlendirmesine açılmasının faydalı olacağı sonucuna ulaşılmıştır.

\author{
Anahtar Kelimeler: Yüksek Denetim, Türk Sayıştayı, Meslektaş Değerlendirmesi
}

JEL Sinıflandırması: H83, M42

\section{Audit of the Supreme Audit Institutions: Country Practices and Turkey}

\begin{abstract}
Supreme Audit Institutions (SAIs) are the audit institutions in each country that supervise the accounts and assets of public institutions. Audit of public institutions, such as the audit of the work of the SAIs with the accounts and operations need to be audited. In the field of auditing of SAIs; three different methods are followed: peer review, examination by independent audit organizations and audit by another country. Especially in the last decade, the audit of the colleague, which the International Organization of Supreme Audit Institutions (INTOSAI) supports and attaches great importance to comes to the fore. In this study, how to audit the SAIs through good practice examples and in this regard, the case of Turkey is examined; It was concluded that it would be useful to open the Turkish Court of Accounts to the peer review.
\end{abstract}

Keywords: Supreme Audit, Turkish Court of Accounts, Peer Review

JEL Classification: H83, M42

Geliș Tarihi / Received: 12.09.2019 Kabul Tarihi / Accepted: 22.11.2019

\footnotetext{
* Dr. Öğr. Üyesi., Afyon Kocatepe Üniversitesi, İ̈BF, Maliye Bölümü, icigerci@aku.edu.tr, ORCID: 0000-00028858-5685.

** Öğr. Gör., Afyon Kocatepe Üniversitesi, Dazkırı MYO, alibalki42@hotmail.com, ORCID: 0000-0002-7130-2001.
} 


\section{GíRiş}

Devletler, sunmuş oldukları kamu hizmetleri ile belirli ekonomik, sosyal, siyasal, mali vb. amaçları gerçekleştirmeye çalışırlar. Kamu hizmetlerini gerçekleştirmek için de harcama yapmak durumundadırlar. Devletlerin genel olarak, kamu hizmetlerini yerine getirirken yaptı̆g 1 harcamaların toplamı kamu harcamaları olarak nitelendirilmektedir. Bunun yanı sıra devletler, kamu harcamalarını karşılamak üzere, gelir toplamak durumundadırlar. Bir devletin, bir yılda yapacağı tahmini harcamalar ile toplayacağı tahmini gelirlerin yer aldığı belgeye bütçe denir.

Hükümetlerin bütçe kapsamında harcama yapabilmesi veya gelir toplayabilmesine olanak sağlayan bütçe hakkı; neredeyse tüm ülkelerde, egemenliğin simgesi olan parlamentolara verilmiş bir haktır. Parlamento, mali yıl başlamadan önce bütçeyi görüşüp onaylayarak (kanunlaştırarak); hükümete bir yılda yapacağı harcamalar ve toplayacağı gelirler için izin vermiş olur. Aslında harcama yetkisi de ülkelerin parlamentolarına verilmiştir. Fakat parlamentolar bu yetkisini bütçe ile (ödenekler itibariyle) her bir harcamacı kuruluşa yani kamu kurumlarına devretmiştir.

Kamu kaynaklarının etkin, ekonomik ve verimli kullanılıp kullanılmadığı, harcamalarının kamu harcama hukuku kurallarına uygun yapılıp yapılmadığı gibi hususların denetimi yine parlamentolara bırakılmıştır. Parlamentolar ise kamu kurumları üzerindeki bu denetim yetkilerini sayıştaylara devretmiştir. Dolayısıyla bir ülkede sayıştay, parlamento adına; kamu harcaması yapan tüm kamu kurum ve kuruluşlarını denetleyen yüksek denetim organıdır.

Nitel araştırma yöntemi kullanılarak yapılan bu çalışmanın amacı; iyi uygulama örnekleri üzerinden sayıştayların nasıl denetimden geçtiğini ve bu anlamda Türk Sayıştayının nasıl denetlendiğini inceleyerek, Türk Sayıştayının meslektaş değerlendirmesine açılmasının faydalı olacağını ortaya koymaktır. Bu bağlamda; Türk Sayıştayının denetlenmesinde yürürlükte olan mevzuatın yeniden düzenlenmesi ve düzenleme yapılırken meslektaş değerlendirmesine açılması, çalışmanın faydası olarak ifade edilebilir. Çalışmada öncelikle yüksek denetim kuruluşu olarak sayıştaylar ele alınmış ve bu kapsamda sayıştayların kurumsal yapıları ve görevleri incelenmiştir. İkinci bölümde ise sayıştayların denetlenmesinde kullanılan yöntemler incelendikten sonra iyi uygulama örnekleri bağlamında; Amerika Birleşik Devletleri, Kanada, Avrupa ve İspanya Sayıştaylarının nasıl denetlendiği üzerinde durulmuştur. Son olarak Türk Sayıştayının mevcut durumda nasıl denetlendiğinden bahsedilmiş ve INTOSAI kapsamında yapılan meslektaş değerlendirmesinin, sayıştayların iş ve işlemlerinin uluslararası standartlara uygunluğu açısından önemli olduğu değerlendirilmiştir.

\section{YÜKSEK DENETIM KURULUŞU OLARAK SAYIŞTAYLAR}

Kamunun hesap verilebilirliği çeşitli yollarla sağlanabilir. Siyasi düzeyde yasama organı, hükümetin hesap verilebilirliğini kurul ve komiteleri aracılığıyla denetler. Kamu hesap verilebilirliği üzerindeki yargı denetimi, ülkelerde anayasanın ayrılmaz bir parçasıdır. Bunun yanı sıra her bir kamu idaresi, kendi içerisinde oluşturduğu iç kontrol mekanizması aracıllğıyla kamu hesap verilebilirliğine katkı sağlar. Yüksek denetim kuruluşları ise kamu hesap verilebilirliğini sağlamak için dış denetim uygulamaktadırlar (Geist, 1981: 3). Ülkelerde dış denetim yapan yüksek denetim kuruluşları "Sayıştay" (Supreme Audit Institution - SAI) olarak adlandırılmaktadır.

Sayıştaylar, hükümetin gelirlerini ve harcamalarını denetlemekten sorumlu ulusal ajanslardır. Her ülkede farklı yasal yetkileri ve amaçları olan sayıştayların asıl amacı, kamu fonlarının yönetimini ve hükümetin rapor edilen finansal verilerinin kalite ve güvenilirliğini denetlemektir (Stapenhurst ve Titsworth, 2002: 1). Sayıştaylar çalışmalarıyla, kamu mali yönetiminin yasalara uygunluğunu, verimliliğini, etkinliğini ve iktisadiliğini denetler. Bu sayede 
sayıştaylar, kamu mali yönetiminin yasalara uygunluğu ve güvenilirliği konusunda geniş bir kitleye tarafsız ve güvenilir bilgiler sunar. $\mathrm{Bu}$ doğrulama ve kontrol mekanizması, güvenilirliklerini topluma göstermek isteyen hükümetler için vazgeçilmezdir (OECD, 2014: 2).

\subsection{Sayıştayların Kurumsal Yapıları}

Sayıştayların kurumsal yapıları ve işlevleri; tarihsel gelişmeler, siyasi sistemler, kültür ve bölgesel ilişkiler gibi birçok nedenden dolayı ülkeden ülkeye değişebilir. Bununla birlikte, dünya genelinde sayıştayların üç farklı modele göre örgütlendikleri görülmektedir: Ofis (Westminster) Modeli, Yarg1 (Judicial-Napoleonic) Modeli ve Kurul (Board-Collegiate) Modeli (Stapenhurst ve Titsworth, 2002: 1; Depertmant for International Development, 2004: 1; Petrica, 2008: 98-99; Yalçın, 2017: 66).

\subsubsection{Ofis Modeli}

Avustralya, Kanada, Hindistan gibi birçok ulus devlet tarafından kullanılan ofis modelinde, Ulusal Denetim Ofisinin başında genel denetçi ya da başkan bulunur. Bu modelde Ulusal Denetim Ofisi adına genel denetçi, meclise rapor veren bağımsız bir organdır. Profesyonel denetçilerden ve teknik uzmanlardan oluşan ofis, devlet kurumlarının mali tabloları ve faaliyetleri hakkında periyodik raporlar sunar. Ofis, devlet kurumlarının faaliyetlerini incelerken mali denetime yoğunlaşır ve yargı modeline göre örgütlenen Sayıştaylara göre daha az yasal uyuma önem verir. Ancak Sayıştay denetimi sırasında, adli yargıyı ilgilendiren bulgular tespit edilirse bunlar, ileri işlemler için yasal makamlara iletilir (Stapenhurst ve Titsworth, 2002: $1-2)$.

Ofis modeline göre örgütlenen sayıştaylar, mali tablo analizleri ile hesap verilebilirliğe katkıda bulunurken; kamu kurumlarına bir nevi danışmanlık hizmeti vererek sunulan kamu hizmetlerinin kalitesini de arttırmaya çalışırlar.

Ofis modelinde Ulusal Denetim Ofisinin başında bulunan ve ofisi temsil eden genel denetçiye olağanüstü yetkiler verilmesi, bazı riskleri de barındırmaktadır. Eğer genel denetçilik makamına getirilen kiş̧i, mesleğin gerektirdiği kişisel özelliklere sahip değilse ve gücünü kötüye kullanırsa; kamu kaynakları etkin kullanılamaz, beraberinde yolsuzluklar da artar (Ogiedu ve Izedonmi, 2013: 195).

Ofis modelinde süreç şu şekilde işlemektedir (Depertmant for International Development, 2004: 2; Yalçın, 2017: 70): Hükümetin bütçe ile talep ettiği ödenekler parlamento tarafından gönderilir. Sayıştay, kamu idarelerinin harcamalarını denetler ve parlamentoya rapor sunar. Sayıştayın sunduğu rapor, parlamento tarafindan oluşturulan Kamu Hesapları Komitesinde görüşülür. Hükümet, Kamu Hesapları Komitesinin tespitlerine cevap vermek zorundadır.

\subsubsection{Yargı Modeli}

Yargı modelinde sayıştay, yürütme ve yasama organlarından bağımsız olarak çalışan yargı sisteminin ayrılmaz bir parçasıdır. Kamu kurumları ve görevlilerinin adli hesap verilebilirliğinde kilit rol oynar. Sayıştay, yapmış olduğu denetimlerde kamu görevlilerinin mevzuata aykırı ödeme yaptığını tespit ederse, bu ödemeden ilgili kamu görevlisini sorumlu tutar (Dye ve Stapenhurst, 1998: 5; Depertmant for International Development, 2004: 5; Santiso, 2007: 8). Özellikle anayasal statüye sahip sayıştaylar, hesap mahkemesi niteliğinde nihai kararlar vermektedir. 
Yargı modelinde sayıştaylar, tüm kamu kurumlarını denetleyerek hükümetin yasalara ve düzenlemelere uyumunu sağlarken kamu kaynaklarının etkin ve verimli kullanılmasına da katkıda bulunur. Yargı modelini uygulayan ülkelere Fransa, İtalya, İspanya, Portekiz ve Türkiye örnek gösterilebilir (Stapenhurst ve Titsworth, 2002: 1; Evans, 2008: 2-3). Bu modele göre örgütlenen sayıştaylar, öncelikli olarak kamu kaynaklarının hukuka uygun kullanıp kullanılmadığını denetlemekte ve kamu kurumlarının performans denetimi ikinci planda kalmaktadır.

Yargı modelinde süreç ve sayıştayın yapmış olduğu işlemler şu şekilde özetlenebilir (Depertmant for International Development, 2004: 6-7): (i) Parlamento bütçe kanunu ile kamu kurumlarının harcama yapabilmesine izin verir. (ii) Maliye Bakanlığı tüm kamu kurumlarının muhasebesinin tutulmasından, ödeneklerin doğru bir şekilde harcanmasından ve yıllık mali tabloların hazırlanmasından sorumludur. Bu kapsamda Maliye Bakanlı̆̆ı; bütçenin uygulanma esaslarını belirleyerek iç denetimde önemli rol oynar. (iii) Sayıştay, kamu kurumları tarafından hazırlanan yıllık mali tabloları denetler. (iv) Sayıştay yapmış olduğu denetim sonucunda yasalara aykırı bir işlem tespit ederse, sorumlu kamu görevlilerine cezai yaptırımlar uygulayabilir. (v.) Maliye Bakanlığı bütçe dönemi sonunda tüm kamu harcamalarını içeren raporu (mali tabloları) hazırlar. Sayıştay, mali yıl içinde her bir kamu idaresinde yaptığı denetimler ile tüm kamu harcamalarını içeren mali tablolarda yaptığ denetimlerin sonucunu bir rapor halinde parlamentoya sunar. Parlamento bu raporla, hükümetin bir yılda yaptığı harcamaların yasalara uygun olup olmadığını görür. Bu ise parlamentoya, hükümete gelecek bir yıl için harcama yetkisi verip vermeme konusunda yardımc1 olur.

\subsubsection{Kurul Modeli}

Kurul modelinde sayıştayların parlamento ile ilişkileri, ofis modelindeki sayıştaylar ile büyük ölçüde aynıdır. Farklılık örgütlenme biçiminde ortaya çıkmaktadır. Ofis modelinde sayıştayı, genel denetçi temsil eder ve tüm yetki ve sorumluluk genel denetçiye aittir. Kurul modelinde ise sayıştay, tek bir kişi tarafından değil bir kurul ya da komite tarafından idare edilir (Blume ve Voigt, 2007: 11). Kararların bir kurul tarafindan uzlaşıyla alınması, sayıştayın daha isabetli karar vermesine yardımcı olur. Ancak bazı durumlarda, kurulun ortak karar alması zorlaşabilir ve sayıştayın işlemleri yavaşlayabilir (Zyl vd., 2009: 14).

Kurul modelinin başlıca özellikleri şu şekildedir (Depertmant for International Development, 2004: 9-10): (i) Bu modelde sayıştay, bir kurul tarafından yönetilir ve kurulun başında bir başkan bulunur. (ii) Sayıştay, her biri kendi sorumluluk alanındaki denetim konularında karar verme yetkisine sahip dairelerden oluşur. Ayrıca dairelerin tartışmalı kararlarını gözden geçiren bir temyiz komitesi de vardır. (iii) Dairelerde bulunan sayıștay üyeleri, çalışma metodolojilerini belirleme konusunda bağımsızdır. (iv.) Sayıştay üyeleri, belirli bir süre için parlamento tarafindan atanır ve görev süreleri genellikle iki dönemle sinırlıdır. (v.) $\mathrm{Bu}$ modele göre örgütlenen sayıştayların çalışmalarının odak noktasını, ülkede geçerli olan hukuki yapı ve bu yapının tarihsel gelişimi ile sayıştay üyelerinin mesleki deneyimleri ve profesyonel geçmişleri etkiler.

Kararlarını kurul tarafindan alarak ofis modelinden, yargısal yetkisinin olmamasıyla yargı modelinden ayrılan kurul modeli; Güney Kore ve Japonya gibi Asya ülkeleri ile Almanya ve Hollanda gibi Kuzey Avrupa ülkelerince benimsenmiştir (Yücel, 2018: 43).

\subsection{Sayıştayların Görevleri}

Yüksek denetim kurumu olan sayıştayların görevleri, sayıştayların örgütlenme modellerine ve ülkelerin hukuki yapısına göre farklılık gösterebilmektedir. Bununla birlikte 
sayıştayların her ülkedeki tartışmasız görevi; kamu gelir ve giderlerinin etkinlik, ekonomiklik, verimlilik ve yasalara uygunluk yönünden denetimini gerçekleştirerek, düzenlemiş olduğu raporları parlamentoya ve kamuoyuna sunmaktır. Ayrıca ülkemizde olduğu gibi yargı modelini benimsemiş ülkelerde sayıştayın, kamu görevlileri hakkında hesap yargılaması yapma görevi ve yetkisi bulunmaktadır.

Sayıştayların genel görevleri ve bu görevleri yerine getirirken uyması gereken standartlar Uluslararası Yüksek Denetim Kurumları Teşkilatı (INTOSAI) tarafindan 1997 yılında yayımlanan Uluslararası Yüksek Denetim Kurumları Standartları 1 (ISSAI 1) Lima Deklarasyonu ile belirlenmiştir.

Genel olarak sayıştayların ilk görevi; kamu kurumlarının muhasebe işlemleri ve mali tabloları ile kamu mali yönetiminin yasalara uygunluğunu ve düzenliliğini denetlemektir. İkinci görevi ise performans denetimi adı altında kamu kurumlarının tüm faaliyetlerini (mali, idari ve kurumsal) verimlilik, etkinlik ve tutumluluk kriterleri çerçevesinde denetlemektir (INTOSAI, 1997: 4). Ayrıca sayıştaylar bu denetimler sonucunda düzenledikleri raporları parlamentoya ve kamuoyuna sunmak zorundadır (INTOSAI, 1997: 8). Buna göre sayıştayların kamu kurumları üzerindeki denetimi, düzenlilik denetimi (uygunluk denetimi ve mali denetim) ve performans denetimi olmak üzere ikiye ayrılmaktadır.

Sayıştaylar, kamu kurumları üzerindeki denetimlerini gerçekleştirirken INTOSAI tarafindan belirlenen dört temel denetim standardına uyarlar. INTOSAI tarafindan yayımlanan temel denetim standartları şu şekildedir: Kamu Denetiminde Temel Prensipler (ISSAI 100), Kamu Denetiminde Genel Standartlar ve Etik Öneme Sahip Standartlar (ISSAI 200), Kamu Denetiminde Alan Standartları (ISSAI 300), Kamu Denetiminde Raporlama Standartları (ISSAI 400).

\section{SAYIŞTAYLARIN DENETLENMESİ}

INTOSAI, kuruluşa üye yaklaş1k 190 yüksek denetim kuruluşunun mevcut kapasitelerini geliştirmek ve uluslararası standartlara uyumunu sağlamak üzere Kapasite Geliştirme Komitesi'ni (Capacity Building Committee - CBC) kurmuştur. 2004 y1lında kurulan CBC, INTOSAI'nin dört ana komitesinden birini oluşturmaktadır.

CBC'nin kapasiteden kastı; bir ülke sayıştayını etkin kılan beceriler, bilgiler ve çalışma şekilleridir. CBC, kapasite geliştirme anlamında; sayıştayların güçlü yönlerini ortaya koyarken zayıf yönlerini ele alıp geliştirmeye çalışmaktadır. Sayıştayların mevcut kapasitelerinin geliştirilmesi için stratejiler belirlenir ve uygulanır. Uygulama sonuçları raporlaştırılarak kapasite geliştirme anlamında ne tür ilerlemelerin kaydedildiği ortaya konur. Bu süreç, CBC tarafindan periyodik olarak tekrarlanır ki kapasite geliştirme konusunda istenilen sonuçlara ulaş1labilsin (INTOSAI, 2008: 8).

Sayıştayların kapasitelerinin geliştirilmesi, iş ve işlemlerinin uluslararası standartlara uygun olarak devam etmesi ve bunun sürdürülebilir hale gelmesinde en etkili araç, yüksek denetim kuruluşu olan sayıştayların bağımsız dış denetime tabi olmasıdır (Köse, 2008: 6).

\subsection{Sayıştayların Denetlenmesinde Uygulanan Yöntemler}

Sayıştayların denetlenmesinde uygulanan yöntemler ülkelere göre farkl1lık gösterebilmektedir. Sayıştayların denetlenmesinde öne çıkan yöntemlerden ilki, bir ülke sayıştayının başka bir ülke sayıştayı tarafından denetlenmesidir. İkinci yöntem; birden fazla ülke sayıştayından seçilerek oluşturulan bir denetim ekibinin ilgili ülke sayıştayını denetlemesidir. Sayıştayların denetlenmesinde üçüncü yöntem; sayıştayın, aynı ülkenin denetim kurumlarından 
seçilen denetçilerin oluşturduğu bir ekip tarafindan denetlenmesidir. Sayıştayların denetlenmesinde tercih edilen bir diğer yöntem ise sayıştayların uluslararası bağımsız denetim şirketleri tarafindan denetlenmesidir. Bu yöntemler içerinde sayıştayların en çok tercih ettiği yöntem, INTOSAI tarafından desteklenen uluslararası meslektaş değerlendirmesidir (Köse, 2008: 7).

Sayıştayların denetlenmesinde, uluslararası meslektaş değerlendirmesi dışındaki yöntemler zaman zaman bazı ülkeler tarafindan tercih edilmiştir. Fakat bu yöntemlerin kalite güvencesi oluşturmada ve uluslararası standartlara uyum sağlamada yetersiz kalması sonucunda, bu ülkeler de INTOSAI kapsamında uluslararası meslektaş değerlendirmesi yöntemiyle sayıştaylarını değerlendirmelere tabi tutmuşlardır. Örneğin; Polonya Sayıştayı denetim uygulamalarını ilk kez Danimarka Sayıştayına denetlettirmiş, fakat sonrasında INTOSAI kapsamında yapılan meslektaş değerlendirmesini tercih etmiş ve beş kez uluslararası meslektaş değerlendirmesi yaptırmıştır. Amerika Birleşik Devletleri (ABD) Sayıştayı, denetim uygulamalarını ilk kez bir bağımsız denetim şirketine denetlettirmiş, sonrasında beş kez INTOSAI kapsamında meslektaş değerlendirmesi yaptırmıştır. Aynı şekilde denetim uygulamalarını ilk kez bağımsız bir denetim şirketine denetlettiren Kanada Sayıştayı da sonrasında uluslararası meslektaş değerlendirmesini tercih ederek, sekiz kez meslektaş değerlendirmesi yaptırmıştır.

\subsection{Meslektaş Değerlendirmesi}

Sayıştayların; bağımsızlı̆̆ını güvence altına alması, faaliyetlerini ve denetimlerini uluslararası standartlara uygun olarak yerine getirebilmesi için hesaplarının ve faaliyetlerinin uluslararası meslektaş değerlendirmesine tabi tutulması son derece önemlidir (Trivedi, 2016: 3).

Meslektaş değerlendirmesi; bir yüksek denetim kurumunun faaliyetlerinin, yüksek denetim kurumlarından seçilecek mesleki yeterliliğe sahip denetçilerden oluşan bir ekip tarafindan uluslararası standartlara uygunluğunun incelenmesidir. Meslektaş değerlendirmesinin en önemli faydası, kalite güvencesi oluşturarak sayıştayların hesap verilebilirliğini sağlamasıdır. Belirli periyotlarla yapılan meslektaş değerlendirmeleri de sayıştayların faaliyetlerinin uluslararası standartlara uygunluğunu tesis etmektedir.

Uluslararası meslektaş değerlendirmelerinde en aktif rol oynayan kurum, INTOSAI bünyesinde kurulan Meslek Değerlendirmeleri Alt Komitesi (Sub-Committee on Peer Review)'dir. Bunun yanı sıra, ülkelerin kamu yönetim sistemlerini ve kamu yönetimi kapasitelerini güçlendirmek üzere $\mathrm{OECD}$ ve Avrupa Birliği (AB)'nin ortak girişimi olarak kurulan Yönetişim ve Yönetimde İyileştirme Desteği (Support for Improvement in Governance and Management - SIGMA) tarafından da sayıştayların denetimi yapılabilmektedir. Sayıştayların meslektaş değerlendirmesine tabi tutulması ile ilgili herhangi bir zorunluluk bulunmamaktadır. Ancak kalite güvencesi oluşturması ve uluslararası standartlara uygunluğu sağlaması açısından, özellikle INTOSAI tarafindan desteklenmektedir.

Meslektaş değerlendirmeleri yoluyla en iyi uygulamaları ve kalite güvencesini teşvik etmek için 13-14 Mart 2006'da INTOSAI CBC bünyesinde Meslektaş Değerlendirmeleri Alt Komitesi kurulmuştur. Kuruluş amacına göre komitenin dört sorumluluk alanı bulunmaktadır (INTOSAI, 2006: 9): (i) INTOSAI'deki mevcut meslektaş değerlendirmesi düzenlemelerini değerlendirmek ve belgelendirmek; (ii) Meslektaş değerlendirmelerinin hem incelemenin yapılacağı sayıştay hem de incelemeyi yapacak olan ekipte bulunan sayıştaylar için faydalı olduğunu gösterecek bir ortamı teşvik etmek; (iii) Meslektaş değerlendirmesi sürecinin nasıl başlatılacağı ve değerlendirmenin nasıl yapılacağına ilişkin rehberler geliştirerek, en iyi uygulama örneklerini sunmak; (iv) Katılımcı sayıştayların kararlaştırdığı gibi meslektaş değerlendirmelerinin sonuçlarını uygun bir şekilde yayımlamaktır. 
Meslektaş değerlendirmesinde, değerlendirmeyi yapacak ekibin oluşturulması son derece önemlidir. Ekip üyeleri mesleki yeterliliğe sahip değillerse, değerlendirme sonucunun güvenilir olması ve kalite güvencesi oluşturması beklenemez. $\mathrm{Bu}$ amaçla meslektaş değerlendirmelerinde ön plana çıkan INTOSAI, Meslektaş Değerlendirmesi Alt Komitesi ile bu süreci organize etmektedir. $\mathrm{Bu}$ kapsamda, meslektaş değerlendirmeleri INTOSAI'nin yayımlamış olduğu rehberlere uygun olarak yürütülmektedir.

Sayıştayların kapasitelerinin geliştirilmesinde, meslektaş değerlendirmelerinin rolü ve önemi; hem 2005-2010 INTOSAI Stratejik Planı'nda hem de 2011-2016 INTOSAI Stratejik Planı'nda vurgulanmıştır (INTOSAI, 2004; INTOSAI, 2010).

1999-2015 döneminde INTOSAI üyesi ülkelerin sayıştaylarının \%28'i meslektaş değerlendirmesi suretiyle denetlenmiştir. Grafik 1'de de görüleceği üzere 2010 yılından itibaren INTOSAI kapsamında uluslararası meslektaş değerlendirmesi yaptıran sayıştayların sayısında ciddi artış yaşanmıştır (INTOSAI, 2016a: 5-6).

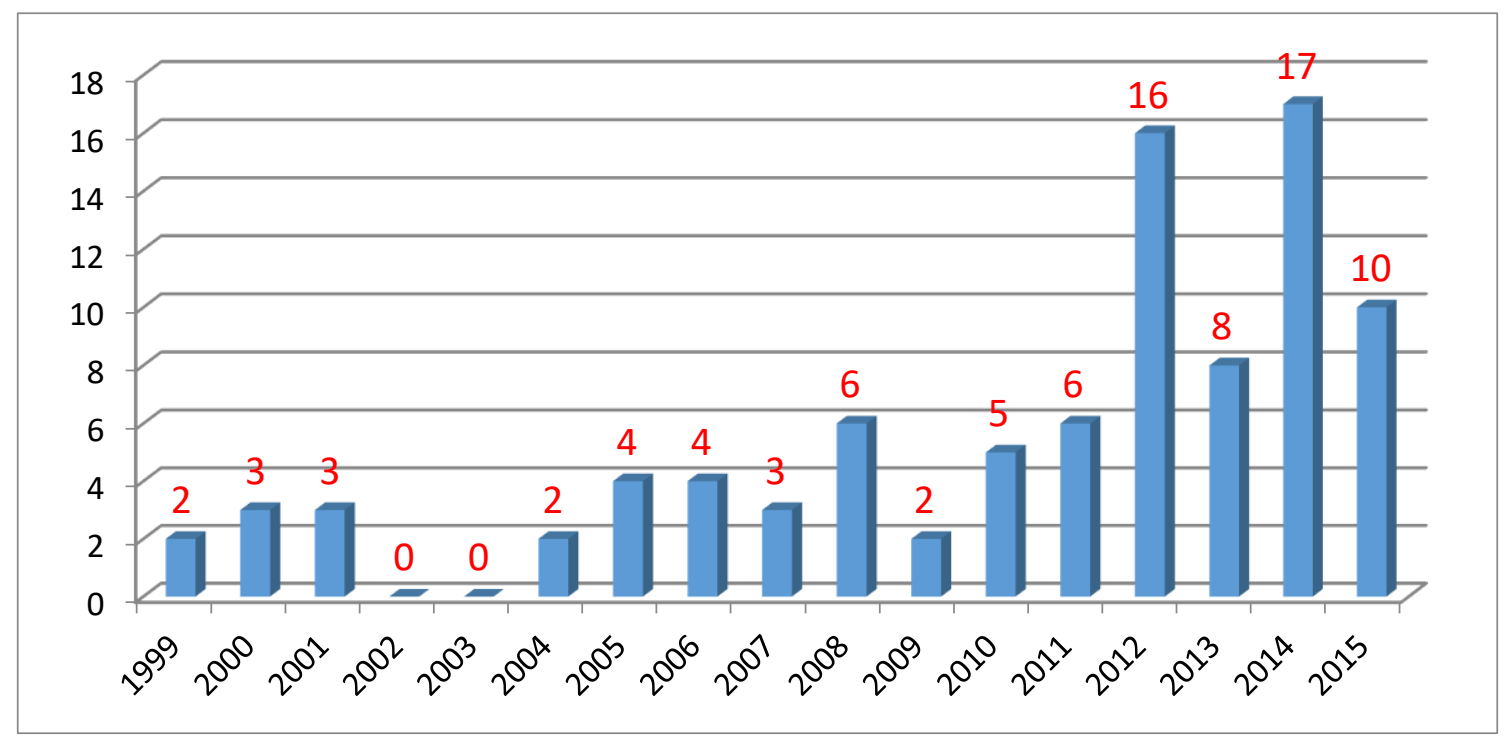

Grafik 1: 1999-2015 Döneminde Yapılan Uluslararası Meslektaş Değerlendirmeleri

Kaynak: INTOSAI (2016a) verileri kullanılarak hazırlanmıştır.

2017-2022 INTOSAI Stratejik Planı'nda ikinci stratejik hedef olarak, sayıştayların kapasitelerinin geliştirilmesi belirlenmiştir. Bu stratejik hedefe ulaşılabilmesi için meslektaş değerlendirmelerinin son derece önemli olduğu vurgulanmıştır. Ayrıca INTOSAI'nin 2017-2022 dönemindeki stratejik önceliklerinin ilki sayıştayların bağımsızlığının savunulması ve desteklenmesidir. Bu kapsamda INTOSAI, sayıştayları ve bir sayıştayın kalite güvence süreçlerinin hayati dış doğrulamasını sağlayan periyodik meslektaş değerlendirmelerine tabi tutmayı teşvik etmeye devam edeceğini belirtmiştir (INTOSAI, 2016b: 2-10).

\section{3. Ülke Uygulamaları}

Sayıştayların denetlenmesinde ülke uygulamaları kapsamında; ABD, Kanada, Avrupa ve İspanya Sayıştaylarının denetlenmesinden bahsedilecektir. Bu ülkelerin seçilmesinin sebebi; $A B D$ ve Kanada Sayıştaylarının ofis modeline göre, Avrupa Sayıştayının kurul modeline göre, 
İspanya Sayıştayının ise yargı modeline göre örgütlenmiş olmasıdır. Bir diğer nedeni ise söz konusu ülkelerin meslektaş değerlendirmesine tabi tutulmasıdır.

\subsubsection{ABD Sayıştayının Denetlenmesi}

İlk kez 1921'de kurulan ABD Sayıştayı, 2004 yılında yapılan düzenleme ile General Accountability Office (GAO) adını almış ve ofis modeline göre örgütlenmiştir. GAO'nun başında bulunan genel denetçi, ABD Senatosu tarafindan on beş yıllığına seçilmektedir. Temel değerleri; hesap verilebilirlik, dürüstlük ve güvenilirlik olan GAO, ABD Kongresini anayasal sorumluluklarını yerine getirme konusunda desteklemekle birlikte performansının artırılmasına ve federal hükümetin hesap verebilirliğinin sağlanmasına yardımcı olmaktadır. ABD Kongresine nesnel, gerçeğe dayalı, bağımsız ve dengeli bilgi sağlamaktadır (GAO, 2007: 1-2).

GAO'nun mali denetim uygulamalarının bağımsız denetimi ilk olarak 1995, 1998, 2001 ve 2004 yıllarında, KPMG International Cooperative (uluslararası bağımsız denetim şirketi) tarafindan yapılmıştır. GAO'nun performans denetim uygulamalarının meslektaş değerlendirmesi ise ilk kez 2004 yılında Kanada, Avustralya, Meksika, Hollanda, Norveç, Güney Afrika ve İsveç Sayıştaylarından oluşan bir denetim ekibi tarafından yapılmıştır (GAO, 2005: 7). ABD Sayıştayının geliştirmiş olduğu, meslektaş değerlendirmesi standartlarına göre, en az üç yılda bir mali denetim ve performans denetimi uygulamaları INTOSAI kapsamında meslektaş değerlendirmesine tabi tutulmaktadır. Bunun yanı sıra GAO'nun iş ve işlemleri, ulusal düzeyde üçer ve beşer y1llık periyotlarla incelenmektedir (GAO, 2005: 15).

GAO'nun mali ve performans denetimi uygulamalarına ilişkin olarak son uluslararası meslektaş değerlendirmesi 2016 yılında Danimarka, Finlandiya, Yeni Zelanda ve Birleşik Krallık Sayıştaylarından oluşan denetim ekibi tarafından yapılmıştır. Bu incelemede GAO'nun; kalite kontrol politikaları ve prosedürleri, iç izleme prosedürleri, gerçekleştirilen denetimler sonucu düzenlenen finansal ve performans denetim raporları ve ilgili belgeleri ile önceki meslektaş değerlendirmelerinde yapılan önerilere cevap verme eylemleri gözden geçirilmiştir (GAO, 2017: 3).

2016 yılına ait meslektaş değerlendirmesi raporunda, GAO'nun iyi uygulamaları içerisinde; (i) Hesap verilebilirlik, doğruluk ve güvenilirlik kriterlerine uygun olarak kalite güvence sistemi oluşturduğu; (ii) Organizasyondaki farklı seviyeleri ve ihtiyaçları desteklemek için tasarlanmış güçlü bir öğrenme ve gelişim stratejisine ve programına sahip olduğu; (iii) Hükümet programlarını değerlendirmek için iki yılda bir yenilenen Yüksek Risk Listesi ve beş noktalı yıldız derecelendirme sistemini kullandığı; (iv) Sosyal medya aracılığıyla etkili iletişimi ön plana çıkardığı; (v) İç paydaş sürecinde birçok uzmanı istihdam ettiği belirtilmiştir (GAO, 2017: 9-12).

Ayrıca, meslektaş değerlendirme ekibi GAO için dikkate değer beş öneri belirlemiştir (GAO, 2017: 13-14): (i) Sözleşme Yönetim Sistemi (EMS)'nin potansiyelini en üst düzeye çıkarmak için bir strateji geliştirmeli; (ii) Raporlarının netliğine ve anlaşılırlığına odaklanmaya devam etmeli; (iii) Düzenlediği raporların birçoğunda oluşturduğu önemli bulgular ve öneriler sayfasının net olmasına daha fazla odaklanmalı; (iv) GAO'nun, yapmış olduğu denetim sonuçlarını 650 karakterle sinırlı olan bir görselde özetlemesi olumlu olmakla birlikte; GAO, bu görseli kamuoyu ve diğer paydaşlarla iletişim kurmak için de kullanmali; (v) Paydaşlarla olan işbirliğini daha da geliştirmek için bir mekanizma geliştirmelidir.

\subsubsection{Kanada Sayıştayının Denetlenmesi}

1878 yılından bu yana bağımsız olarak faaliyet gösteren Kanada Sayıştayı (Office of the Auditor General of Canada - OAG), ofis modeline göre örgütlenmiştir. OAG'yi temsil eden 
genel denetçi, Avam Kamarası ve Senato Meclisi kararıyla 10 yıllığına atanmaktadır. Hükümetin tüm faaliyetleri ile çevresel ve sürdürülebilir kalkınma konularında denetim yapma yetkisine sahip olan OAG; mali denetim, performans denetimi ve özel denetim uygulamalarını gerçekleştirmektedir (OAG, 2019).

Her yıl, Kanada Hazine Kurulu tarafından atanan bir dış denetçi, OAG'nin mali tablolarını denetlemektedir. Denetçinin raporu Hazine Kuruluna sunulmakta ve Avam Kamarasında görüşülmektedir. OAG ayrıca, çalışmalarını gönüllü olarak bağımsız dış incelemelere tabi tutmaktadır. 1999 yılında OAG'nin mali denetimler için geliştirdiği kalite yönetim sistemi, bağımsız bir diş denetim şirketi tarafindan incelenmiştir. INTOSAI kapsamında ilk meslektaş değerlendirmesi ise 2003 yılında, Birleşik Krallık Sayıştayı başkanlığında oluşan bir denetim ekibi tarafından OAG'nin performans denetimi uygulamaları incelenmiştir (OAG, 2019).

OAG'nin ikinci uluslararası meslektaş değerlendirmesi ise 2009 yılında yapılmıştır. Avustralya Sayıştayının başkanlık ettiği denetim ekibinin diğer üyeleri ise Hollanda, Danimarka, İsveç ve Norveç Sayıştaylarından seçilmiştir. Bu değerlendirmede; OAG'nin Eylül 2008 - Ekim 2009 dönemine ait performans denetimi, yıllık mali denetim ve özel denetim uygulamaları incelenmiştir (OAG, 2010: 1-2).

2009 yılında yapılan uluslararası meslektaş değerlendirmesinde tespit edilen, diğer ülke sayıştaylarına da örnek olabilecek OAG'nin iyi uygulama örnekleri şöyledir (OAG, 2010: 7-8); (i) Parlamento ile ilişkilerin iyi yönetilmesi; (ii) Performans denetim raporlarında, kamuoyuna açık ve tutarlı bir mesaj verilmesi; (iii) OAG'nin diğer ulusal denetim ofisleri ile birlikte gerçekleştirdiği ortak denetimlerde, sorunların daha kapsamlı bir şekilde ele alınmasıdır.

Ayrıca meslektaş değerlendirmesi sonucunda denetim ekibi, OAG'ye şu önerilerde bulunmuştur (OAG, 2010: 6-8): (i) Denetimlerden ve paydaş anketlerinden alınan derslerle OAG, daha sağlam ve sistematik bir süreç geliştirmeli ve uygulamalıdır. (ii) Performans denetimi ve özel denetim raporlarının ekindeki dayanak belgelerde yer alan karmaşık sayısal veriler, grafikler ve tablolar kullanılarak geliştirilebilir. (iii) Yıllık mali denetim bulgularını, önem ve risk düzeyine göre sıralayıp bulguların takibini kolaylaştıracak bir sınıflandırma sistemi geliştirilmelidir. (iv) Elektronik ortamda yapılan mali denetimlerde, elektronik denetim çalışma kâğıtları kullanılmalıdır.

\subsubsection{Avrupa Sayıştayının Denetlenmesi}

1977 y1lında kurulup 1993 yılında tam teşekküllü bir AB Kurumu haline gelen Avrupa Sayıştayı (The European Court of Auditors-ECA)'nın amacı; AB'nin finansmanının yönetilme şeklini geliştirerek güvence tavsiye yoluyla $\mathrm{AB}$ bütçesinin uygulanması konusunda kamu hesap verilebilirliğine katkıda bulunmaktır (Laffan, 1999: 254-255).

AB'nin dış denetçisi olan Avrupa Sayıştayının odak noktası; AB'nin finansal raporlaması ile bütçesinin ve politikalarının uygulanmasıdır. Bu kapsamda ECA, birliğe üye ülkelerin sayıştaylarıyla uyumlu olarak; finansal denetim, uygunluk denetimi ve performans denetimi yapmaktadır. Avrupa Sayıştayının isminde her ne kadar "Court - Mahkeme" kelimesi geçse de yapmış olduğu denetimler sonucunda verdiği kararların tam bir yaptırım gücü olmadığından, Avrupa Sayıştayının örgütlenme biçiminin kurul modeline daha yakın olduğu söylenebilir.

Avrupa Sayıştayının INTOSAI kapsamında ilk meslektaş değerlendirmesi 2008 yılında yapılmıştır. Kanada, Avusturya, Norveç ve Portekiz Sayıştayları tarafından yürütülen bu değerlendirmede; Avrupa Sayıştayının denetim ve idari faaliyetleri tüm yönleriyle incelenmiştir. 
2008 yılında yapılan meslektaş değerlendirmesi sonucunda düzenlenen raporda; ECA tarafindan oluşturulan denetim çerçevesinin uluslararası denetim standartlarına ve yüksek denetim kurumlarının iyi uygulamalarına uygun olarak tasarlandığı; ECA'nın çalışmalarını bağımsız ve tarafsız bir şekilde yürüttüğü; incelenen ECA denetim raporlarının, uluslararası denetim standartlarının gerektirdiği şekilde yeterli ve uygun denetim kanıtlarına dayandırıldığı; denetim ekibinin görüştüğü paydaşların, ECA'nın raporlarına büyük güven duyduğu ve genel olarak adil, olgusal ve objektif olduklarını düşündüğü belirtilmiştir (ECA, 2008).

Avrupa Sayıştayının ikinci meslektaş değerlendirmesi ise 2013 yılında yapılmıştır. Almanya Sayıştayının başkanlığında oluşturulan denetim ekibinin diğer üyeleri Fransa ve İsveç Sayıştaylarından seçilmiştir. 2013 yılında yapılan meslektaş değerlendirmesinde; ECA'nın yapmış olduğu performans denetimi uygulamaları incelenirken, 2008 yılında yapılan meslektaş değerlendirmesinde önerilen tavsiyelerin de takibi yapılmıştır.

2013 y1lında yapılan meslektaş değerlendirmesi sonucunda düzenlenen raporda, ECA'nın performans denetimi uygulamaları ile ilgili denetim ekibinin tavsiyelerinin bazıları şunlardır (ECA, 2014: 18-24): (i) ECA'nın yapmış olduğu performans denetimi uygulamaları genel olarak uluslararası standartlara uygun olmakla birlikte; ECA'nın paydaşlarının önceliklerini belirlemek ve bunlarla ilgilenmek için net ve kısa kurallar getirmesi gerekmektedir. (ii) Paydaşların fazla olmasından kaynaklı, ECA'nın hızlı yanıt vermesini gerektirecek çok sayıda beklenmeyen sorun olabilir. (iii) INTOSAI'nın sorun odaklı performans denetimi olarak tanımladığ 1 denetimlere daha fazla ağırlık verilmelidir. (iv) Performans denetimlerinde, birden fazla ülke yerine tek bir ülkenin seçilmesi daha avantajlı olacaktır. (v) ECA'nın denetim prosedürlerini hızlandırmak ve verimliliklerini arttırmak amacıyla denetim hazırlık aşamalarının yeniden yapılandırılması uygun olacaktır.

Ayrıca, 2014 yılında yayımlanan meslektaş değerlendirmesi raporunda; 2008 yılında yapılan değerlendirme sonucunda yapılan tavsiyelerin büyük çoğunluğunun yerine getirildiği belirtilmiştir (ECA, 2014: 43-48).

\subsection{4. İspanya Sayıştayının Denetlenmesi}

Yüksek mahkeme olarak ilk kuruluşu 1800'lü y1llara dayanan İspanya Sayıştayı (Tribunal de Cuentas - TCu), yargı modeline göre örgütlenmiştir. TCu ile ilgili bugüne kadar birçok düzenleme yapılmakla birlikte, en son 1978 Anayasası ile devletin üst denetim organı olarak, yürütme yetkisinden bağımsız ve doğrudan İspanya Parlamentosu ile bağlantılı olarak yapılandırılmıştır (TCu, 2019a).

İspanya Sayıştayının denetim ve yargı olmak üzere iki fonksiyonu bulunmaktadır. Denetim fonksiyonu kapsamında $\mathrm{TCu}$, tüm kamu idarelerinin; mali yönetimi ve faaliyetlerinin yasal ve düzenleyici hükümlere uygunluğunu (uygunluk denetimi); mali tabloların mevcut muhasebe standartlarına uygun olup olmadığını (mali denetim) ve faaliyetlerin verimlilik, etkinlik, tutumluluk kriterlerine uygun olarak gerçekleştirilip gerçekleştirilmediğini (performans denetimi) denetlemektedir ( $\mathrm{TCu}, 2019 \mathrm{~b}$ ). TCu, yargı fonksiyonunu; kamu mallarını ve fonlarını idare edenlerin hesap verilebilirlik kriterine uygun olarak, kasıtlı davranış ya da ağır ihmalleri sonucu ortaya çıkacak kamu zararlarının tespiti ve tazmini konusunda bağlayıcı kararlar vererek yerine getirir (TCu, 2019c).

İspanya Sayıştayının INTOSAI kapsamında meslektaş değerlendirmesi, Avrupa, Portekiz ve İspanya Sayıştaylarından oluşan bir denetim ekibi tarafından 2014 yılında yapılmıştır. Bu incelemede; TCu'nun faaliyetlerinin yasal çerçevesi, uluslararası denetim ve etik standartlara, özellikle de ISSAI standartlarına uygunluğu değerlendirilmiş, TCu'nun iyi 
uygulamaları tespit edilerek bağımsızlık, şeffaflık, yönetim, denetim ve yargı fonksiyonları gibi önemli alanlarda ilgili hususları iyileştirmek için önerilerde bulunulmuştur (TCu, 2015: 9-13).

2014 yılında yapılan meslektaş değerlendirmesi sonucunda düzenlenen raporda; TCu'nun modern, şeffaf, bağımsız ve etkili bir yüksek denetim kurumu olarak işlev görmesini sağlayacak güçlü araçlara sahip sağlam bir kurum olduğu; son yıllarda TCu'nun çalışma kalitesini iyileştirmek ve geliştirmek için iyi uygulamaları modernize etmeye ve benimsemeye çalıştı̆̆ belirtilmiştir (TCu, 2015: 7).

Ayrıca, meslektaş değerlendirmesi raporunda şu tavsiyelere yer verilmiştir $(\mathrm{TCu}, 2015$ : 11): (i) Sektörel stratejilerin yanı sıra ölçülebilir hedefleri de içeren net, kurumsal bir strateji geliştirilmelidir. (ii) Performans kriterleri ve ayrıntıları ile $\mathrm{TCu}$ üyelerinin görev sürelerinin uzunluğu gözden geçirilmelidir. (iii) $\mathrm{TCu}$ içinde açık iş tanımları ve önceden tanımlanmış hedeflere karşı y1llık değerlendirmeler üzerine kurulu, performansa dayalı bir çalışma ortamı oluşturulmalıdır. (iv) Sürekli mesleki gelişimin kilit bir unsur olduğu bilgi temelli bir çalışma kültürü geliştirilmelidir. (v) Denetim raporlarının zamanında, kolay okunabilir ve kısa-net olmasına özen gösterilmelidir. (vi) Eksiksiz bir kalite kontrol sistemi oluşturulmalıdır. (vii) Meslektaş değerlendirmesindeki tavsiyelerin takibi için bir sistem geliştirilmelidir. (viii) TCu'nun yargı prosedürlerini basitleştirmek, daha tutarlı ve eksiksiz hale getirmek için yasal çerçevede bir reform yapılmalıdır.

İspanya Sayıştayı, 2018-2021 Stratejik Planı'nda; kurumsal yönetimin iyileştirilmesinin ve hesap verilebilirliğin sürdürülebilirliğinin meslektaş değerlendirmesine bağl1 olduğunu ve bunun için de meslektaş incelemelerine devam edeceğini belirtmiştir (TCu, 2018: 3).

\subsection{Türk Sayıștayının Denetlenmesi}

Yasama ve yürütme organından bağımsız hareket eden, kamu görevlilerinin hesap ve işlemlerini kesin hükme bağlayan ve yargı sisteminin bir parçası olan Türk Sayıştayı; sayıştayların örgütlenme modellerinden yargı modeline göre örgütlenmiş bir yüksek denetim kuruluşudur.

Köklü bir geçmişe sahip olan Türk Sayıştayının bağımsız dış değerlendirmesi yapılmamaktadır. Sadece 5018 sayılı Kamu Mali Yönetimi ve Kontrol Kanunu'nun 69. maddesine göre, Sayıştayın denetlenmesi; her yıl TBMM adına TBMM Başkanlık Divanı tarafindan görevlendirilen ve gerekli mesleki niteliklere sahip denetim elemanlarından oluşan bir komisyon tarafindan, hesaplar ve bunlara ilişkin belgeler de esas alınarak yapılmaktadır. Yapılan bu denetim, yalnızca 5018 sayılı Kanun kapsamında Sayıştayın hesaplarına ilişsin bir denetimdir. INTOSAI'nin belirlemiş olduğu Uluslararası Denetim Standartları kapsamında Sayıştayın tüm iş ve işlemlerine ilişkin bir değerlendirme değildir. Fakat Sayıştayın 2019-2023 Startejik Planı'nda (Sayıştay Başkanlığı, 2018: 55); Sayıştayın faaliyetlerine yönelik olarak kalite güvence sisteminin kurulması, INTOSAI kapsamında meslektaş değerlendirmelerine başlanılması ve bu meslektaş değerlendirmelerinin düzenli hale getirilmesi gerektiği belirtilmiştir.

Köse'nin (2008: 38) çalışmasında da belirttiği üzere; TBMM Başkanlık Divanı tarafından Sayıştayı denetlemekle görevlendirilen denetim elemanlarının birçoğunun Sayıştayın denetimi kapsamında olan kamu kurumlarında çalışan denetim elemanlarından oluşması denetimin doğasına aykırıdır.

Ayrıca, 3.12.2010 tarihli ve 6085 sayılı Sayıştay Kanunu'nun 79. maddesinde yer alan Sayıştayın denetlenmesine ilişkin yasal düzenleme, Anayasa Mahkemesi'nin 28.2.2013 tarihli ve E. 2011 L21, K. 2013/36 sayılı kararı ile iptal edilmiştir. 
Yüksek Mahkeme, gerek Anayasa'nın 87. maddesinde yer alan TBMM'nin görev ve yetkileri, gerekse 160. maddesinde yer alan Sayıştayın denetiminin kapsamını, yetki ve görevlerini konu alan düzenlemeler bağlamında bir değerlendirme yapmış, 6085 sayılı Kanun'un 79. maddesini Anayasa'ya aykırı bularak iptal etmiştir. Söz konusu madde iptal edilmeden önce Sayıştayın denetiminin, her yıl TBMM adına yine TBMM Başkanlık Divanı tarafından görevlendirilen ve gerekli mesleki niteliklere sahip denetim elemanlarından oluşan bir komisyon tarafindan yapılacağı hüküm altına almaktaydı. Kanunların anayasaya uygunluk denetimi ve bu denetimin sonucunda verilen iptal kararlarının uygulanması bakımından herhangi bir sıkıntı gözükmese de 5018 sayılı Kanun'un 69. maddesindeki Sayıştayın denetlenmesi başlıklı hükmün iptal edilen 6085 sayılı Kanun'un 79. maddesi ile aynı olması anayasa hukuku açısından bir tartışmaya sebebiyet vermiştir. Söz konusu tartışmanın temelinde Anayasa Mahkemesinin 6085 sayılı Kanun'un 79. maddesini iptalinden sonra hala yürürlükte olan 5018 sayılı Kanun'un 69. maddesinin mi uygulanacağ 1 yoksa Anayasa Mahkemesinin kararı doğrultusunda mı denetim yapılacağına ilişkindir.

Anayasa Mahkemesi 6085 sayılı Kanun'un 79. maddesini iptal ederek, Sayıştayın kendi denetiminin yine Sayıştay tarafindan yapılması gerektiğini ancak denetimin bağımsızlığının ve tarafsızlığının güvence altına alınabilmesi için denetimi yürütecek ekibin Sayıştay Başkanı tarafindan değil Sayıştay Genel Kurulu tarafindan belirlenmesi gerektiğine dair karar vermiştir.

Her ne kadar Anayasa Mahkemesi 6085 sayılı Kanun'daki ilgili madde için iptal kararı vermiş olsa da yürürlükteki 5018 sayılı Kanun'un 69. maddesinin uygulanma durumunun ortadan kalktığını söylemek pozitif hukuk açısından mümkün görünmemektedir. Anayasa Mahkemesince iptal edilmemiş hali hazırda yürürlükte olan 5018 sayılı Kanun'un 69. maddesi Sayıştayın denetiminin, TBMM adına yine TBMM tarafından görevlendirilen, mesleki yeterliliğe sahip denetim elemanlarından oluşan bir komisyonca yapılması gerektiğini ifade etmektedir. Gerek kanunilik ilkesi, gerekse hukuki güvenlik ilkesi nazarından bakıldığında 5018 sayılı Kanun'un uygulanması gerektiğini ifade etmek gerekmektedir. Nitekim Sayıştaydaki uygulamalara bakıldığında da her yıl Sayıştay denetiminin TBMM tarafindan görevlendirilen kamu kurumlarının denetim elemanlarından (Mülkiye Müfettişleri gibi) oluşan bir komisyon tarafindan yapılmaya devam edildiği görülmektedir. Sayıştayın denetlenmesine ilişkin Anayasa Mahkemesinin iptal kararı ile ortaya çıkan bu durumun çözüme kavuşturulması gerekmektedir. Yani içeriği tamamen aynı olan fakat farklı kanunlarda yer alan iki hükümden birinin Yüksek Mahkemece iptal edilmesi karşısında yasa koyucu, 5018 sayılı Kanun'un 69. maddesinin yürürlükte olduğunu da hesaba katarak yeni bir düzenlemeye gidebilir.

\section{SONUÇ}

Yüksek denetim kuruluşu olan sayıştayların, parlamento adına ülkedeki tüm kamu kurum ve kuruluşlarının gelir ve gider hesapları ile mallarını denetleyerek sonucunda parlamentoya ve kamuoyuna raporlar sunması, sayıştayların ne derece önemli bir görevinin olduğunu ortaya koymaktadır. Sayıştaylar bu görevlerini yerine getirirken, özellikle kamuoyundaki güvenilirliğini daima muhafaza etmelidir. Onun için sayıştaylar, yapmış oldukları denetimleri ve düzenledikleri raporları makul güvence oluşturacak şekilde yapar ve düzenlerler.

Sayıştayların denetimlerinde dikkat edecekleri hususları ve uluslararası standartları INTOSAI belirlemiştir. Türk Sayıştayı da bu kapsamda, yapmış olduğu tüm iş ve işlemlerde INTOSAI tarafından belirlenen uluslararası standartlara uymaya çalışmaktadır.

Birçok ülke, sayıştaylarının iş ve işlemlerini uluslararası bağımsız dış denetime açmıştır. Sayıştayların uluslararası bağımsız diş denetime tabi tutulması, uluslararası denetim standartlarına ne derece uyup uymadıklarını ortaya koyarken, aynı zamanda kendilerini 
geliştirmesine de önemli katkılar sağlamaktadır. Fakat Türk Sayıştayında, uluslararası bağımsız dış denetimi yapılmamaktadır.

Ülkemizde Sayıştayın yalnızca hesapları ve bunlara ilişkin belgeleri, TBMM Başkanlık Divanı tarafindan oluşturulan komisyon tarafından denetlenmektedir. Sayıştayı denetleyecek komisyon üyelerinin, Sayıştay denetimine tabi kamu kurumların denetim elemanları arasından seçilmesi ise denetimin doğasına aykırılık teşkil etmektedir. Ayrıca ülkemizde 5018 sayılı Kanun'un 69. ve 6085 sayılı Kanun'un 79. maddelerine istinaden Sayıştayın denetlenmesine devam edilirken, Anayasa Mahkemesi 2013 yılında 6085 sayılı Kanun'un 79. maddesini iptal etmiştir. Hâlbuki 6085 sayılı Kanun hazırlanırken 79. madde, 5018 sayılı Kanun'un 69. maddesinden aynen alınmıştır. Bununla birlikte 5018 sayılı Kanun'un 69. maddesi halen yürürlükte olup, bu maddeye istinaden Sayıştayın denetlenmesine devam edilmektedir.

Anayasa Mahkemesinin iptal kararından bu yana Sayıștayın denetlenmesi ile ilgili yeni bir düzenleme yapılmamıştır. Fakat konu ile ilgili yeni bir düzenleme yapılması gerektiği aşikârdır. Sayıştayın denetlenmesi ile ilgili yeni düzenleme yapılırken, Sayıştayın iş ve işlemlerinin belirli periyotlarla (üç yıllık ya da beş yıllık gibi) INTOSAI kapsamında uluslararası meslektaş değerlendirmesine açılması yerinde olacaktır.

\section{KAYNAKÇA}

Blume, L. ve Voigt, S. (2007), 'Supreme Audit Institutions: Supremely Superfluous? A Cross Country Assessment', International Centre for Economic Research, Working Paper No. 3/2007, [Çevrim-içi: ftp://ftp.repec.org/opt/ReDIF/RePEc/icr/ wp2007/ICERwp03-07.pdf], Erişim tarihi: 09.01.2019.

Department for International Development (2004), Characteristics of Different External Audit Systems: Briefing, [Çevrim-içi: https://webarchive.nationalarchives.gov.uk/+/http:/ www.dfid.gov.uk/aboutDFID/organisation/pfma/pfma-externalaudit-briefing.pdf], Erişim tarihi: 12.12.2018.

Dye, K.M. ve Stapenhurst, R. (1998), Pillars of Integrity: The Importance of Supreme Audit Institutions in Curbing Corruption, The Economic Development Institute of the World Bank.

Evans, A. (2008), The Role of Supreme Audit Institutions in Combating Corruption, U4 Anti-Corruption Resourch Centre, Transparency International, [Çevrim-içi: https://www.u4.no/ publications/the-role-of-supreme-auditinstitutions-in-combating-corruption.pdf], Erişim tarihi: 08.01.2019.

Geist, B. (1981), 'State Audit: An Introduction, State of Israel, State Comproller's Office, [Çevrim-içi: https://link.springer.com/chapter/10.1007/978-1-349-04666-9_1], Erişim tarihi: 12.12.2018.

General Accountability Office (GAO) (2005), Peer Review Assuring Quality and Enhancing Confidence, [Çevrim-içi: https://www.gao.gov/assets/80/78414.pdf], Erişim tarihi: 11.02.2019.

General Accountability Office (GAO) (2007), Congressional Research Service Report for Congress, [Çevrim-içi: https://apps.dtic.mil/dtic/tr/fulltext/u2/a469940.pdf], Erişim tarihi: 11.02.2019.

General Accountability Office (GAO) (2017), International Peer Review of the Performance and Financial Audit Practices of the United States Government Accountability Office, [Çevrim-içi: https://www.gao.gov/assets/690/687903.pdf], Erişim tarihi: 11.02.2019.

International Organization of Supreme Audit Institutions (INTOSAI) (1977), ISSAI 1 - The Lima Declaration, The IXth Congress of the International Organization of Supreme Audit Institutions.

International Organization of Supreme Audit Institutions (INTOSAI) (2004), INTOSAI Strategic Plan 2005 - 2010, [Çevrim-içi: https://www.nku.gov.sk/documents/10272/1273416/ INTOSAI+Strategic+plan+2005+-+2010.pdf], Erişim tarihi: 07.02.2019.

International Organization of Supreme Audit Institutions (INTOSAI) (2006), The Inaugural Meeting of the INTOSAI Capacity Building Committee, London, [Çevrim-içi: https://www.nku.gov.sk/documents/10272/1273416/Minutes_CBC+meeting_London_2007En/7efb2fe3-50c3-47169a61-73df98762951], Erişim tarihi: 14.12.2018.

International Organization of Supreme Audit Institutions (INTOSAI) (2008), Development of INTOSAI Capacity Building Committee, INTOSAI Capacity Building Committee Subcommittee 2 Meeting, Lima, Peru. 
International Organization of Supreme Audit Institutions (INTOSAI) (2010), INTOSAI Strategic Plan 2011 - 2016 , [Çevrim-içi: http://www.intosai.org/uploads/intosaispenglish v9web.pdf], Erişim tarihi: 07.02.2019.

International Organization of Supreme Audit Institutions (INTOSAI) (2016a), Sub-Committee on Peer Review: Progress Report, Congress Secretariat, XXII INCOSAI Aseel Building, Abu Dhabi, United Arab Emirats.

International Organization of Supreme Audit Institutions (INTOSAI) (2016b), INTOSAI Strategic Plan 2017 - 2022, [Çevrim-içi: http://www.intosai.org/fileadmin/downloads/downloads/ 1_about_us/strategic_plan/EN_INTOSAI_Strategic_Plan_2017_22.pdf], Erişim tarihi: 07.02.2019.

Köse, H.Ö. (2008), Sayıştay Denetiminin Denetlenmesi: Uluslararası Uygulama Örnekleri Çerçevesinde Bir Değerlendirme, Sayıştay Dergisi, 70.

Laffan, B. (1999), Becoming a 'Living Institution': The Evolution of the European Court of Auditors, Journal of Common Market Studies, 37(2).

OECD (2014), Partners for Good Governance: Mapping the Role of Supreme Audit Institutions, Public Governance and Territorial Development Directorate Public Governance Committee, Paris: OECD Headquarters.

Office of the Auditor General of Canada (OAG) (2010), International Peer Review Report of the Office of the Auditor General of [Çevrim-içi: Canada, http://www.ourcommons.ca/Content/ Committee/403/PACP/Reports/RP4797595/403_PACP_Rpt20/403_PACP_Rpt20-e.pdf], Erişim tarihi: 10.02.2019.

Office of the Auditor General of Canada (OAG) (2019), About the Office of the Auditor General of Canada, [Çevrimiçi: http://www.oag-bvg.gc.ca], Erişim tarihi: 10.02.2019.

Ogiedu, K.O. ve Izedonmi, F.I.O. (2013), Topology of Audit agency/ Audit Techniques and the Effectiveness of the Nigerian Supreme Audit Institution, Research Journal of Finance and Accounting, 4(6).

Petrica, S. (2008), External Audit Systems, Studies and Scientific Researches, 13, University of Bacau, Romanya.

Santiso, C. (2007), Eyes Wide Shut? The Politics of Autonomous Audit Agencies in Emerging Economies, Documento de Trabajo, CIPPEC, [Çevrim-içi: https://www.cippec.org/wp-content/uploads/ 2017/03/2074.pdf], Erişim tarihi: 08.01.2019.

Stapenhurst, R. ve Titsworth, J. (2002), Features and Functions of Supreme Audit Institutions, Quality and Knowledge Financial Management, [Çevrim-içi: https://openknowledge. worldbank.org/bitstream/handle/10986/9766/multi0page.pdf;sequence=1], Erişim tarihi: 12.12.2018.

T.C. Sayıştay Başkanlığı (2018), Stratejik Plan 2019-2023, [Çevrim-içi: https://www.sayistay.gov.tr /tr/Upload/76662805/files/SAYI\%C5\%9ETAY\%20STRATEJ\%C4\%B0K\%20PLANI\%202019-2023(1).pdf], Erişim tarihi: 05.02.2019.

The European Court of Auditors (ECA) (2008), International Peer Review Report of the European Court of Auditors, [Çevrim-içi: https://www.eca.europa.eu/Lists/ECADocuments/ PEERREVIEW2008/PEERREVIEW2008_EN.PDF], Erişim tarihi: 07.02.2019.

The European Court of Auditors (ECA) (2014), International Peer Review Report of the European Court of Auditors, [Çevrim-içi: https://eca.europa.eu/Lists/ECADocuments/2013_PEER _REVIEW/2013_PEER_REVIEW_EN.pdf], Erişim tarihi: 07.02.2019.

Tribunal de Cuentas of Spain (TCu) (2015), Report: Peer Review of the Tribunal de Cuentas of Spain, [Çevrim-içi: https://www.tcu.es/tribunal-de-cuentas/export/sites/default/.content/pdf/ transparencia/Report_PR_2015_06_23-fimen.pdf], Erişim tarihi: 12.02.2019.

Tribunal de Cuentas of Spain (TCu) (2018), Strategic Plan 2018 - 2021, [Çevrim-içi: https://www.tcu.es /tribunal-decuentas/export/sites/default/.content/pdf/PLAN_ESTRATEGICO_2018-2021.pdf], Erişim tarihi: 12.02.2019.

Tribunal de Cuentas of Spain (TCu) (2019a), History of the Tribunal de Cuentas of Spain, [Çevrim-içi: https://www.tcu.es/tribunal-de-cuentas/en/la-institucion/historia/], Erişim tarihi: 12.02.2019.

Tribunal de Cuentas of Spain (TCu) (2019b), Audit Function of the Tribunal de Cuentas of Spain, [Çevrim-içi: https://www.tcu.es/tribunal-de-cuentas/en/fiscalizacion/funcion-de-fiscalizacion/], Erişim tarihi: 12.02.2019.

Tribunal de Cuentas of Spain (TCu) (2019c), Prosecution of Accounting Liability Function of the Tribunal de Cuentas of Spain, [Çevrim-içi: https://www.tcu.es/tribunal-de-cuentas/en/enjuiciamiento/funcion-de-enjuiciamiento/], Erişim tarihi: 12.02.2019.

Trivedi, P. (2016), Auditing the Auditors: Evaluating the Methodology of Performance Audits, Indian School of Business WP 2871102, [Çevrim-içi: https://papers.ssrn.com/sol3/ papers.cfm?abstract_id=2871102], Erişim tarihi: 06.02.2019. 
Yalçın, S. (2017), Yüksek Denetim Kurumlarının Kurumsal Yapısı ve Mali Performans, T.C. Sayıştay Başkanlığı Yayınları, No: 114, Ankara.

Yücel, Ö. (2018), Kamu Mali Yönetim Sisteminde Seçilmiş Ülke Sayıştayları ve Türk Sayıştayı Analizi, Süleyman Demirel Üniversitesi Sosyal Bilimler Enstitüsü, Yüksek Lisans Tezi, Isparta.

Zyl, A.V., Ramkumar, V. ve Renzio, P. (2009), Responding to the Challenges of Supreme Audit Institutions: Can Legislatures and Civil Society Help?, U4 Anti-Corruption Resourch Centre, Chr. Michelsen Institute, Bergen, Norway. 


\section{Extended Summary}

\section{Audit of the Supreme Audit Institutions: Country Practices and Turkey}

Supreme Audit Institutions (SAIs) are the audit institutions in each country that supervise the accounts and assets of public institutions. Audit of public institutions, such as the audit of the work of the SAIs with the accounts and operations need to be audited. The aim of this study is to use qualitative research method; examining how the SAIs are audited on the basis of good practice examples and how the Turkish Court of Accounts is audited in this sense, revealing that it would be beneficial to open the Turkish Court of Accounts to peer review. In this context; the reorganization of the legislation in force in the audit of the Turkish Court of Accounts and the opening of it to peer review while making the regulation can be stated as the benefit of the study.

Institutional structures and functions of SAIs; It can vary from country to country for many reasons such as historical developments, political systems, culture and regional relations. However, SAIs around the world are organized according to three different models: the Westminster Model, the Judicial - Napoleonic Model and the Board - Collegiate Model. In the Westminster Model, the National Audit Office is headed by a general auditor. In this model, the general auditor on behalf of the National Audit Office is an independent body reporting to the parliament. The office focuses on financial auditing when examining the activities of government agencies and places less emphasis on legal compliance than the SAIs organized according to the Judicial Model. In this model, the SAI is an integral part of the judicial system, which operates independently of the executive and legislative bodies. In the Judicial Model, SAIs audit all public institutions and ensure government compliance with laws and regulations while contributing to efficient and efficient use of public resources. The Board Model differs from the Westminster Model by taking its decisions by the board and from the Judicial Model due to the lack of judicial authority.

The methods used to audit SAIs may vary by country. One of the prominent methods in auditing SAIs is the auditing of one country's SAI by another country's SAI. The second method; the audit is the audit of the SAI by a team of auditors selected from the SAIs. The third method of auditing SAIs is; audit by a team of auditors selected from audit institutions of the same country. Another preferred method of auditing SAIs is audit of SAIs by international independent audit companies. Among these methods, the most preferred method of SAIs is the international peer review supported by INTOSAI.

Peer review; the compliance of the activities of a higher audit institution with international standards by a team of professionally qualified auditors to be selected from the supreme audit institutions. The most important benefit of peer review is that it ensures accountability of SAIs by creating quality assurance. Peer reviews conducted at regular intervals also establish the compliance of SAI's activities with international standards. In peer review, it is very important to form a team to make the evaluation. If the team members do not have professional competence, the evaluation result cannot be expected to be reliable and quality assurance. For this purpose, INTOSAI, which stands out in peer review, organizes this process with the Peer Review Sub-Committee. In this context, peer reviews are conducted in accordance with the guidelines published by INTOSAI.

Within the scope of country practices in the audit of SAIs; the audit of the SAIs of the United States, Canada, Europe and Spain was examined. The reason for the selection of these countries General Accountability Office and Office of the Auditor General of Canada are organized according to the Westminster Model, The European Court of Auditors is established 
according to the Board Model and Tribunal de Cuentas is organized according to the Judicial Model. Another reason is that these countries are subject to peer review.

The Turkish Court of Auditors, which acts independently of the legislative and executive organs, finalizes the accounts and procedures of public officials and is a part of the judicial model; is one of the organizational models of SAIs. Many countries have opened the work and procedures of their SAIs to independent international audit. The SAIs are subject to international independent external auditing, while determining whether they comply with international auditing standards or not, they also contribute to the development of themselves. However, the Turkish Court of Auditors does not conduct external independent audits.

In our country, only the accounts of the Turkish Court of Accounts and their documents are audited by the commission established by the Presidential Council of the Grand National Assembly of Turkey. The fact that the commission members to audit the SAI from among the audit staff of the public institutions subject to the audit of the Turkish Court of Accounts is contrary to the nature of the audit. As a result, the legislation in force in the audit of the Turkish Court of Accounts should be rearranged and during the regulation opened to peer review. 
Optimum Journal of Economics and Management Sciences, Vo1. 7, No. 1- http://dergipark.gov.trloptimum Ciğerci and Balkl - Audit of The Supreme Audit Institutions: Country Practices and Turkey 